\title{
Carnets
}

Revue électronique d'études françaises de l'APEF

Première Série - 4 Numéro Spécial | 2012

Invasions \& Évasions

\section{O Moderno do Antigo: A estesia cívica do jovem Almeida Garrett nas Revoluções Liberais ibéricas}

Joana Duarte Bernardes

\section{OpenEdition}

1 Journals

Edição electrónica

URL: http://journals.openedition.org/carnets/7503

DOI: $10.4000 /$ carnets. 7503

ISSN: 1646-7698

Editora

APEF

Edição impressa

Data de publição: 1 Junho 2012

Paginação: 121-146

Refêrencia eletrónica

Joana Duarte Bernardes, «O Moderno do Antigo: A estesia cívica do jovem Almeida Garrett nas Revoluções Liberais ibéricas », Carnets [Online], Première Série - 4 Numéro Spécial | 2012, posto online no dia 23 junho 2018, consultado o 03 maio 2019. URL : http://journals.openedition.org/carnets/7503 ; DOI : 10.4000/carnets.7503

\section{(c) (i) (8)}

Carnets est mis à disposition selon les termes de la licence Creative Commons - Atribution - Pas d'utilisation commerciale 4.0 International. 


\section{O MODERNO DO ANTIGO}

\section{A estesia cívica do jovem Almeida Garrett nas Revoluções Liberais ibéricas*}

JOANA DUARTE BERNARDES

CEIS 20 / Universidade de Coimbra

joanaduarteb@gmail.com

\section{Resumo}

Se o Romantismo parecia anunciar o advento do "novo", este necessitou igualmente de convocar um certo tipo de "antigo". Mas também os cultores do "antigo", sujeitos agora aos impactos das lutas antinapoleónicas, cantarão o "novo" em configurações classicistas. Para o provar, privilegiar-se-á a análise de textos literários - com destaque para Almeida Garrett -, cruzando-a quer com os seus pressupostos canónicos, quer com o núcleo duro do seu vocabulário conceptual (pátria, patriotismo, revolução, tirania, despotismo, liberdade, etc.). Porém, sendo uma terminologia dos clássicos, era também o vocabulário dos modernos, sobretudo para os liberais, em Espanha (Constituição de Cádis, 1812) e em Portugal (1820-22), que sobrepuseram o seu uso àquele que tinha sido feito pelos tradicionalistas anti-napoleónicos.

\section{Abstract}

If Romanticism seemed to announce the advent of the "new", the "ancient" never ceased to be called for. That is the case of anti-Napoleonic movements, a voice of the "new" featuring the "ancient" through its meanings and forms. In order to prove it, we will privilege literary texts, focusing on Almeida Garrett, taking into account their canonic principles and their conceptual vocabulary (homeland, patriotism, revolution, tyranny, despotism, freedom, etc.). However, if this is a terminology eminently under the influence of the Classics, it also inspired the vocabulary of the Modern, mainly for the Liberals, in Spain (Cadiz Constitution, 1812) and in Portugal (1820-22), who superimpose its usage to the employ coined by the anti-Napoleonic traditionalists.

Palavras-chave: Garrett, pátria, tirania, Revolução, Constituição.

Keywords: Garrett, homeland, tyranny, Revolution, Constitution.

\footnotetext{
* Uma versão menos completa do presente texto foi entretanto publicada no Brasil em Jacqueline Hermann, Francisca Nogueira de Azevedo e Fernando Catroga (org.), Memória, escrita da história e cultura política no mundo luso-brasileiro, Rio de Janeiro, Fundação Getúlio Vargas, 2012, pp. 251-284.
} 
Introdução

Ignorar a dívida de Almeida Garrett, mormente no que diz respeito às suas criações da juventude, para com a gramática do respublicanismo que circulava na Europa do Sul de então, bem como nas colónias americanas dos países ibéricos, será não levar devidamente em conta o epíteto que ele próprio escolheu para si: o de "Alceu da Revolução". Com efeito, assim se define e se decide o que foi o posicionamento crítico do jovem escritor em tempos de indefinição política e diante do lastro caótico que as invasões napoleónicas e, depois, as repercussões liberalizantes que as lutas que desencadearam, tiveram em Portugal e nos seus domínios coloniais (Brasil). Na verdade, a cega subordinação da retórica política ao magistral império do estético de que Garrett foi, indubitavelmente, voz e pena, pode fazer perigar a própria hermenêutica textual, na medida em que despe a metáfora daquilo que, segundo Nietzsche, é o seu objecto: a verdade. Nos efeitos visados pelo jovem escritor ecoava a recepção do cenário literário espanhol, francês ou inglês inspirado no paradigma que a queda da República romana às mãos da usurpação de César ofereceu, em crescendo desde o século XVII, a uma vasta literatura de matiz patriótico (que glosou amiúde, os exempla de figuras como Catão e Brutus). Porém, não apenas. O legado clássico enformou, também, a partilha activa e irmã que, em resposta tão cívica quanto apaixonada, avolumava nos países do Sul as hostes patrióticas na sua luta contra as novas reactualizações do despotismo, fossem elas encarnadas por Napoleão, ou pelos áulicos que tinham feito da Monarquia uma instituição antipatriótica e fomentadora do servilismo.

Contudo, esta problemática não pode ser confinada a reflexões de tipo nacionalista, já que os seus ideais tiveram uma circulação transnacional e baseavam-se na defesa de um valor de vocação universal, porque inferida a partir dos direitos naturais do homem: a Liberdade. Daí que o ajustamento do liberalismo à gramática da velha cultura respublicana (Maurizio Viroli, 2011; Fernando Catroga, 2011) tenha acabado por atravessar todas as formas discursivas e, como é lógico, também as obras dos escritores que mais se comprometeram na sua realização histórica.

Só quem perfilhar uma concepção excessivamente dicotómica das relações entre o "antigo" e o "moderno" e entre o "universal" e o "concreto" poderá achar abusiva a possibilidade de as experiências históricas, imbuídas de memórias e de expectativas, poderem dar rostos ao passado e concretude ao universal, em função das especificidades históricas dos povos e dos problemas que defrontam. Neste último caso, importa lembrar que nem os pensadores comummente identificados com a tendência mais cosmopolita do Iluminismo - incluindo Kant - escamotearam esta dialéctica.

Daí a importância de se recorrer à história comparada e, no que agora nos interessa, ao que ocorreu em Espanha, sobretudo porque o movimento que maior influência 
exerceu na história portuguesa desta conjuntura (tal como nas colónias da hoje designada América Latina) teve início com revoltas anti-napoleónicas que, ao eclodirem em Maio de 1808, virão a desembocar na revolução e na Constituição liberal de Cádis (1808-1812). Ora, se este processo não foi alheio ao impacto da Revolução Francesa (principalmente da sua primeira fase), a cultura política caditiana, ao irradiar para Portugal e para as Américas sob a égide da colonização ibérica, veio dar um novo alento, nos dois lados do Atlântico, ao ideal patriótico. Sendo assim, a hermenêutica da linguagem e finalidade da literatura que o irá defender será sempre lacunar ao ignorar-se que ela mantém uma intrínseca relação interconceptual com a linguagem política do tempo da sua produção.

Nesse sentido, a escolha de textos como Catão ou "O Brasil liberto" reveste-se de suma pertinência já que a sua matriz traduz parte da encruzilhada da modernidade histórica e política de Portugal - e de certa Europa. Tendo por alvo a tirania mas condenando o tiranicídio, Catão recria, diante do espelho português - e face à desmesura europeia -, a emergência do cesarismo e o revigoramento do despotismo como massacre da Liberdade. Mas não só. A universalidade do supremo valor defendido - a libertação dos povos do jugo despótico -, não só transpunha fronteiras nacionais (de que o caso da Península lbérica é exemplo), como unia, sob o mesmo canto de guerra, quer revolucionários como conservadores. Será, pois, a poética do patriotismo (comprovada pela proliferação vocabular dos seus derivados, como veremos) a expressão uníssona dos ideais respublicanos, evidência da lição do antigo nas acesas lutas do moderno.

É a Liberdade reposta em Cádis (1812-1814), e que teve na proclamação do documento constitucional o momento máximo da sua expressão pública, que é possível ler em Garrett - e não a simples imitação estética de uma revolução que, começando a estender-se às colónias, viria a saldar-se nos movimentos emancipatórios destas. A particularidade do caso português terá em "O Brasil liberto" altifalante sonoro. Com efeito, escrito em 1821, o poema garrettiano - pensado à luz da constitucionalização liberal do Reino Unido de Portugal, Brasil e Algarves (1815), mas também da permanente ameaça do regresso do absolutismo - servirá para comprovar a força e a primazia que a ideia de Liberdade tinha sobre interesses que mais tarde serão caracterizados como "nacionalistas". Mas, por ele, também se deseja sugerir que o jovem Garrett, em convívio estreito com a comunidade dos estudantes brasileiros em Coimbra, já possuía consciência de que o lugar que o novo Portugal podia ocupar na "balança da Europa" passava muito pelo que estava a ocorrer na América Ibérica e, em particular, no Brasil.

Patriotismo, Constituição e virtude cívica: palavras antigas para uma revolução moderna Se se fizer um levantamento lexical, quer nos artigos garrettianos publicados no jornal coimbrão O Patriota, quer nos textos que virão a ser incluídos na compilação da obra 
lírica, encontramos um uso frequente de substantivos como pátria, liberdade, virtude, patriotismo, cidadão, igualdade, nação, bem como de outras expressões, de conotação francamente pejorativa, como servo, escravo, tirania, tirano, despotismo (Verdelho, 1981; Godoy, 1998; Godechot, 1973; Catroga, 2008). Ora, uma análise diacrónica e comparativa permite-nos constatar que esta é uma tipologia florescente na literatura europeia ligada a temas cívicos e a momentos revolucionários. Assim foi na Inglaterra das revoluções do século XVII, na Revolução Francesa, nos movimentos anti-napoleónicos e nos levantamentos populares da Península Ibérica contra Napoleão (e, extensivamente, nas revoluções liberais que aqui tiveram a sua origem). Assim será, também, na onda descolonizadora que atravessará a América do Centro e do Sul.

Todas as entificações da pátria e da liberdade estão sob a égide de um ideal patriótico que defendia a congregação de todas as pátrias locais através de um vínculo de ordem contratual que permitisse ao cidadão o exercício da virtude cívica e da liberdade. A substantivação da ideia de pátria cívica passava, pois, pela assunção da sua voz pelo corpo revolucionário (Robespierre, 1965; Saint-Just, 2004)루, facto potenciado pelas características que ela foi assumindo, antes e depois das convulsões revolucionárias. A madre patria, expressão recorrente nos discursos caditianos de Augustín Argüelles e exemplar no que diz respeito à natureza do conceito (Catroga, 2008), ainda que manifestamente referencie aquela pátria que, pensada como vínculo jurídico-político assente no direito, faz da cidadania a condição da liberdade, transporta consigo toda a valoração afectiva própria das patriae loci. Com efeito, os usos da palavra, independentemente das variações sémicas e da ambiguidade semântica ocasionada pela ocorrência de outros vocábulos (mormente nação e estado), remetem sempre para uma metaforização emotiva, que faz da pátria o termo mais quente de uma escala de temperatura afectiva (Fernández Sebastián, 2005). Sendo a terra dos pais, sendo a paisagem, a pátria é terra que a vista alcança (Godoy, 1998) e cuja possibilidade de apreensão denuncia uma marcação física do eu (por conseguinte, a emergência de um efeito aurático advindo do húmus) e uma de-marcação memorial que, pressupondo a distância temporal e (muitas vezes) geográfica, compreende a presença de outros tornados patrícios (a família e a vizinhança) ${ }^{2}$.

\footnotetext{
${ }^{1} \mathrm{O}$ caso francês assumirá as especificidades ditadas pelo processo revolucionário. Com efeito, se é verdade que, desde as primeiras utilizações (século XVI), em contexto literário de conotações claramente política, a palavra patrie (em concorrência com a forma latina patria, que serviu quer os pensadores políticos da Idade Média, quer a cultura do Renascimento) surge como antónimo de tirania, mas não necessariamente de monarquia, o decurso da revolução hipostasiará o "amour sacré de la Patrie", bem patente nos cânticos revolucionários tais como La Marseillaise ou "Ah Ça ira!", dele fazendo a legitimação do interesse público e do povo, enfant e défenseur, enquanto ídolos em nome dos quais o passado pátrio deveria ser sacrificado. A pátria que a Revolução, paulatinamente, vai construindo acabará por distanciar-se da retórica afectiva, rumo à Grande Nação, protagonizada por Napoleão Bonaparte: este passa a ser o principal mediador entre pátria e povo, na medida em que faz do sentimento patriótico aliado da aventura imperial (Monnier, 2006: 11-59); Steuckardt, 2006: 135-158).

2 Por um lado, estímulo raiz contemplativa, por outro, fundo memorial, a pátria é dotada de um carácter fixo, característica que é acentuada pelo seu cariz memorial. A experiência da pátria é, teoricamente, finita, facto que
} 
Definindo, pois, o sentimento pátrio - o patriotismo - como uma fidelidade ${ }^{3}$, o que implica uma relação sacrificial e um vínculo que é da ordem do sentimento, mesmo na sua acepção mais local e comunitária e, portanto, subjectiva, existe nele sempre uma dimensão contratualista. Ora, quando em causa está a transposição das afectividades das pátriaspaisagem para a justificação de uma patria civitatis na qual o cidadão deverá ser o protagonista da virtude cívica, procede-se à exaltação desse valor afectivo para que se possa cumprir um ideal que diz respeito a uma comunidade maior - fora dos limites da paisagem e projecção de uma virtude cidadã. Ser virtuoso seria, pois, observar a lei e participar na sua instituição (Catroga, 2009ª), de forma a impedir a mácula da tirania sobre a ordem pública. A ameaça da tirania e da usurpação sentida pelos antigos seria coarctada pelo que Cícero veio a definir e a defender como "regime misto". Ao tornar activa a participação da aristocracia e da plebe na res publica, estabelecia-se a ponderação dos poderes, meio antigo para a moderna prática da soberania e para o arrazoamento da representação.

Desta feita, dizer-se que as revoluções liberais, enquanto movimento pautado pela defesa da liberdade individual como instrumento da realização colectiva, empunhou uma ideia de pátria sentida como um conjunto de irmãos e de filhos livres, ligados entre si através do uso da liberdade norteado para um bem comum, equivale a aceitar-se que a ordem pública promanaria de uma Lei que objectivasse princípios inferidos a partir da natureza humana. Neste contexto, pátria deixa de ser apenas um acidente de ordem biogeográfica, para, ainda que não podendo prescindir desse sentido, dizer respeito a um sentimento de pertença constitucionalizado.

O investimento feito pelos movimentos revolucionários neste patriotismo constitucional e o peso concedido à génese afectiva do sentimento pátrio surgem estreitamente ligados ao tipo de ordenamento jurídico-político que lhes serviu de matriz. Com efeito, com o advento da moderna concepção do tempo e com a emergência das teorizações sobre o contrato social, o carácter patriótico e constitucional das Revoluções em curso assumiu matizes diferentes, com repercussões a nível das representações e das práticas revolucionárias. E se tal faz emergir não apenas os modos de integrar e/ou superar o antigo nos novos valores ideológicos e civis que a nova era ia inaugurando, tem,

\footnotetext{
a representificação anamnética vinca: "Une patrie se compose des morts qui l'ont fondée aussi bien des vivants qui la continuent” (Renan, 1887) ; “On n'emporte pas la patrie à la semelle de ses souliers !”, frase alegadamente proferida por G. J. Danton, justificando, em resposta a Louis Legendre, por que motivo não quis fugir para o exílio.

${ }^{3}$ É Ortega y Gasset quem explicitamente o faz, no seu texto "Introdução sobre o que é uma paisagem": "Meus senhores, o patriotismo é antes de mais a fidelidade à paisagem, à nossa limitação, ao nosso destino. Olhai como actualmente os homens da Europa lutam por conservar cada qual a sua paisagem" (Ortega y Gasset, 2007: 47. O referido texto terá sido apresentado em conferência em 4 de Abril de 1915, no Ateneu de Madrid durante a primeira Guerra Mundial.
} 
outrossim, implicações quer a nível das concessões políticas feitas, quer a nível dos meios convocados para esse efeito.

\section{O caso francês}

A elaboração da primeira Constituição francesa (1791) não deixa margem para dúvidas. Identificando o jusnaturalismo como o princípio de justiça que deve reger a relação entre o homem e as coisas, a norma contratualista corporizada pela Constituição devia traduzir um acto legislativo supremo, anterior às leis positivas e dimanada somente do povo (Locke, 1824). Esta premissa, de resto, bem patente no incipit escolhido para abrir a Constituição Americana (1787) - We the people -, pressupõe a aceitação de uma lei natural, disposta pelo estado de natureza, alicerçada nos ideais de Igualdade e Liberdade (Locke, 1824: 133).

Ao fazer radicar no contrato social a construção de uma sociedade nova, rasurados que deviam ser o passado absolutista e a exploração tirânica da pátria, os sentimentos patrióticos surgiam no contexto francês como uma compensação de ordem afectiva (Catroga, 2008; Rosanvallon, 2004). O ser cidadão relegava o indivíduo para uma posição mais abstracta, na medida em que os corpos intermédios haviam sido abolidos ${ }^{4}$. E, se tal acabará por ter efeitos na consolidação das novas formas de sociabilidade emergentes desde as Luzes (o círculo, a festa, o café - as circunstâncias de convivialidade geradoras de laços sociais e de identidades), a nível da luta revolucionária, o novo documento jurídico, fonte primacial da República una e indivisível, deveria surgir como prova e protecção de uma corporação geral de cidadãos. Por esta razão, a Constituição francesa de 91 projectava o princípio de unidade, enquanto garante de segurança e ordem, e a inviabilidade dos corpos intermédios, enquanto potenciais separadores do cidadão da res publica (Le Chapelier). A oscilação permanente entre Liberdade e Instituição, ao mesmo tempo que dotava o cidadão das ideais condições para o cumprimento da virtude cívica, tornava evidente o vazio deixado pela anulação dos corpos intermédios. O mesmo será dizer que, se a extinção das corporações históricas demandava o preenchimento desse lapso societário, a anulação da instituição monárquica, absolutista, atingia quer a construção de uma sociedade inter-individual, quer a lógica policial e legislativa em que a Revolução buscava as suas fundações.

\footnotetext{
${ }^{4}$ Leia-se, no texto da Constituição de 1791, os pressupostos iniciais, anteriores às disposições fundamentais: "Il n'y a plus ni jurandes, ni corporations de professions, arts et métiers"; "La loi ne reconnaît plus ni voeux religieux, ni aucun autre engagement qui serait contraire aux droits naturels ou à la Constitution" (in http://www.conseilconstitutionnel.fr/conseil-constitutionnel/francais/la-constitution/les-constitutions-de-la-france/constitution-de1791.5082.html - 11-01-2010).
} 
No entanto, deve dizer-se em abono da verdade, que, em 1791, na primeira Constituição lavrada pelos revolucionários, o caminho para que a Revolução se consolidasse não passava pela radicalização que, em 1793 há-de ser alcançada e acabará por ditar a decapitação de Luís XVI. Em '91, instituía-se o papel do rei na distribuição equilibrado dos poderes, fazendo do juramento da Constituição pelo monarca a exigência para que este pudesse tornar-se roi des français - seu título único - e não apenas roi de France et de Navarre. E isto significa que, num primeiro momento, a Revolução francesa conviveu e fomentou uma monarquia constitucional, que conferia ao monarca uma posição claramente de subordinação, já que reinava em nome da Lei e pela vontade do povo ${ }^{5}$. Assim, a translatio imperii dava-se daquela para o monarca que, em momento algum, podia violar o novo pactum subjectionis. O não juramento da Constituição equivaleria ao acto de abdicar-se do trono - e o seu não cumprimento seria crime julgado como traição à pátria.

O amor pela igualdade perante a Lei, sendo o factor de união e coesão social, definiria as modernas democracias (Montesquieu, 1854: p. 206), nas quais o interesse público deveria estar acima do indivíduo. E, como esta é a natureza da sociedade civil, seria inata a necessidade de representação social e de um pacto que congregasse os interesses pátrios. O que justifica a anomalia de um regime absolutista ou tirânico, no qual o governo de um materializava a antagónica presença dos valores prejudiciais à res publica: a autosuficiência neutralizadora dos laços sociais e, por conseguinte, a instalação do medo. De onde, a identificação do tirano com um traidor, inimigo e imolador da pátria. Na medida em que, no caso francês, a rasura do Antigo Regime deveria compreender a instauração de uma sociedade nova (o que implicaria uma nova cidade, uma nova organização, uma nova religião, um novo calendário) (Baczko, 2001), a aceleração do tempo - que tem no Terror a máxima expressão do papel conversor e activo do revolucionário - era posta em andamento para que a felicidade comum pudesse ser atingida. Norteada a Revolução para uma nomocracia absoluta, o tiranicídio, como modo último de exercer a virtude cívica e de, simultaneamente, encarnar o fim do corpo místico e do corpo físico da Monarquia vinha representar o acto mais radical e dramático da Revolução Francesa: abreviar a espera da nação em nome da pátria.

Significa isto que o patriotismo que assiste à feitura da Constituição de '93 - e que confirmaria a República - reconhecerá na Monarquia a impossibilidade de servir os interesses da pátria e o estado dos cidadãos. Assim se extremava o jus resistendi (Catroga, 2009; Ugartemendia Eceizabarrena, 1999). A partir do momento em que a lei é a liberdade (Talleyrand) e esta garantia para o estado geral, o déspota, entronizando o arbitrário,

\footnotetext{
${ }^{5}$ Ibidem, "Il n'y a point en France d'autorités supérieures à celle de la loi. Le roi ne règne que par elle, et ce n'est qu'au nom de la loi qu'il peut exiger l'obéissance".
} 
antepunha-se ao bem comum em função de um universo particular, pelo que a intervenção tiranicida seria aceite já que visava cercear o poder da autoridade pública vigente.

\section{O caso espanhol}

Entre a necessidade de ocultar as evidentes influências revolucionárias inspiradas em França e a manifesta adesão a um constitucionalismo de matriz histórica o processo de Cádis oscilou entre a criação de uma Constituição nova e a restauração das antigas leis fundamentais. Com efeito, se esta dualidade de posições acabou por fragilizar a primeira geração liberal em Espanha, na medida em que o formato constitucional, ao pretender equilibrar os desígnios revolucionários com a tradição historicista, acabaria por negar à Constituição os fundamentos de ordem cultural que impediriam a vitória final do conservadorismo ${ }^{6}$, ela dá conta do cerco ideológico aos trâmites que o processo libertador deveria assumir.

Num primeiro momento, as aspirações revolucionárias de ambas as facções direccionam-se para uma mesma finalidade: contra o poder arbitrário do invasor Napoleão, a convocação de Cortes (Jovellanos, 1962), forma tradicional de representação que aproximava os objectivos da elite esclarecida e dos conservadores. As diferenças entre ambos diziam respeito, essencialmente, à organização temporal da mudança a cumprir. Se os revolucionários radicais lutavam pela criação de uma nova sociedade sujeita a uma Constituição igualitária (Florez Estrada, 1958: 322), os constitucionalistas históricos reivindicavam a organização corporativa e o restabelecimento dos antigos privilégios que o Absolutismo tinha liquidado. Entre revolução e restauração, o processo revolucionário em Espanha mobilizava ainda alguns absolutistas, apoiantes do constitucionalismo histórico, mas contra quem a acção revolucionária, radical ou historicista, se organizou para que a Revolução pudesse dar os seus primeiros passos. Todavia, como as Cortes gozavam de pouco poder, estando também sujeitas à arbitrariedade do chamado despotismo ministerial, cedo a defesa de uma Constituição nova se impôs como caminho único para que a salvaguarda das liberdades do povo - pensado agora como um todo igual e cidadão - fosse atingida. O que significava, uma vez mais, a identificação da Lei Fundamental com a Liberdade e a sua inexistência com o despotismo.

Assim, já na proposta constitucional de Álvaro Florez Estrada (1809), contra uma tirania dupla (o imperialismo napoleónico e o governo despótico monárquico), só a existência de leis criadas fora da Razão pode explicar a sobrevivência do estado absolutista

\footnotetext{
${ }^{6}$ Recorde-se que a Constituição política da Monarquia Espanhola, promulgada em Cádis a 12 de Março de 1812, esteve em vigência apenas dois anos, até ao regresso de Fernando VII (García Cárcel, 2007; Guerra, 2009).
} 
(no caso espanhol, iniciado com a subida ao trono de Carlos IV, em 1788). A lei fundamental existente carecia ainda dos mecanismos necessários à execução e ao cumprimento da Lei, o que propiciará o governo arbitrário de príncipes e ministros. Registava, desta forma, a ilegitimidade do governo de um (Florez Estrada,1958: 313) e a falácia de uma representação nacional nestas condições. O mesmo é dizer: "Sin libertad no hay patria. El hombre esclavo jamás puede contar com patria alguna por más que ame aquella en que ha nacido y que para conservarla cumpla todos los deberes que le imponga su razón y aun el capricho del que manda" (Florez Estrada, 1958: 313).

O discurso patriótico surge, pois, como sucedâneo lógico da denúncia da tirania e da necessidade de dotar a Nação de uma Constituição para que a Pátria possa ser vivida pelos seus filhos como pertença a uma totalidade composta por cidadãos iguais. De resto, o discurso oficial plasmava um vocabulário que ecoava pelas ruas de Cádis durante a ocupação napoleónica. Canções como "Los defensores de la patria" (posteriormente convertida no "Himno de Riego"), "Himno de la victoria" ou a famosa "Trágala", escritas aquando das invasões napoleónicas, dão conta de um vocabulário patriótico que acompanha a evolução do conceito. Com efeito, a "pátria" deixa de figurar apenas nos dicionários para se converter em aclamação popular (Godoy, 1998: 138), facto que terá na onda revolucionária desencadeada pelo General Rafael de Riego exemplo máximo.

A hoje designada por Guerra da Independência - marcada pela actuação decisiva do povo a ponto de se criar um mito populista, usado por Pérez Galdós (e de, na revolução de 1868, Fernando Garrido comparar o heroísmo do povo de 1808 com a inoperância de então) - marcou decisivamente a consciencialização da ideia de pátria, já não como terra dos pais, mas, sobretudo, como um conjunto de cidadãos ligados por um laço político assente no princípio da Liberdade. No entanto, também se sabe que a experiência que culminou na aprovação da Constituição de 1812 foi fugaz, pois o absolutismo regressou logo em 1814, na sequência da célebre conspiração dos "persas". Mas, quando, nos inícios de 1820, o processo, encabeçado por Riego, renasceu, serão ainda os mesmos valores que voltarão a ganhar um uso redobrado. De onde o teor do seu imperativo cívico: "Todo es poco sacrificio para ella; a la Patria se lo debe todo. Sin embargo, amigos mios, no sirva la exaltación para hacer locuras: saquemos mejor fruto dellas [...]. De outro modo no mereceríamos el título de hombres libres, porque habríamos dejado de ser virtuosos (Riego, 1976: 34).

O que está em causa, sobretudo, nos discursos de Riego é o exercício de um ius resistendi firmado na forte convicção na soberania constitucional e na monarquia (desde que "mista") como instituição primeira de exemplaridade da prática cívica. E, por isso, "El Rey, que debe su trono a cuantos lucharon en la guerra de la Independencia, no ha jurado, sin embargo, la Constitución; la Constitución, pacto entre el Monarca y el pueblo, cimiento y encarnación de toda Nación moderna." (Riego, 1976: 35). A metamorfose do sentimento de 
pertença não perdia a carga emotiva, na medida em que se exaltava o sacrifício que transformava os cidadãos em soldados com o recurso à metáfora maternal, o que, por outro lado, reiterava o carácter parricida do tirano ${ }^{7}$.

Sob o impacto de uma Liberdade à qual se chegava através do contrato social, a constitucionalização da virtude cívica, dependendo da difusão de sentimentalidades pátrias para que se levasse a cabo a construção da nação, actualizava a definição aventada por Cícero para patria civitatis: módulo congregador da expressão da virtude cívica e do novo pacto social. E, portanto, Martínez de la Rosa (em 1808, professor de Filosofia Moral da Universidade de Granada e deputado nas Cortes de Cádis de que a Constituição saiu em 1812), no seu poema Saragoça, escrito em 1809, declara: "guerra eterna/ guerra á la usurpación: muramos todos / antes que vernos las torpes plantas de bárbaros verdugos, / sin libertad, sin patria, arrodillados"8 (Martínez de la Rosa, 1837: 22). Pátria e Liberdade surgem identificadas, sendo que esta identificação, longe de ser arbitrária, pressupõe uma ideia de liberdade constitucionalizada - e, por isso, cívica. Enquanto resposta ao despotismo, as pequenas pátrias das afectividades locais deveriam ampliar-se de maneira a que os valores da patria civitatis fossem congregadores de um sacrifício nacional. A revitalização de uma virtude respublicana, em que homem e cidadão voltam a ser considerados como uma unidade, foi, pois, parte produtora e produto de um todo nacional (Desmons, 2001).

Identificado o monarca absolutista com a força opressora e não perdendo de vista que a Monarquia fora, a par da Igreja, o veículo da "pátria comum" tradicional, a aniquilação das velhas alianças, feita em nome da nova instância unificadora - a soberania nacional -, demandava que a primazia fosse concedida ao patriotismo cívico, isto é, a um sentimento de pertença que, fundado num sistema representativo, pudesse estabelecer os alicerces de uma nova pátria, desta feita, imbuída já de uma pátria nacional. A crença, antiga e actualizada pelas Luzes (Jaucourt, Rousseau, Robespierre, Saint-Just, etc), de que não existe pátria onde só existe despotismo, e identificado este com o Absolutismo, levava a que essa nova pátria harmonizasse os enraizamentos mais imediatos à patria naturae com um projecto de sociedade contratual:

No ha sido en el gran día

El altar de la patria alzado en vano

\footnotetext{
${ }^{7}$ Definia assim Manuel José Quintana a patria, em composição dedicada a José Padilla, um dos mártires da Guerra de las Comunidades de Castilla (1520-1522): "Pátria! Nombre feliz, númen divino, / Eterna fuente de virtud, en donde / Su inestinguible ardor beben los buenos; / Pátria!... (...) Virtud, pátria, valor: tal fué el sendero / Que vo os abri primero" (Quintana, 1867: pp. 3-4).

${ }^{8} \mathrm{E}$, por isso, o Duque de Rivas, no seu El Desterrado, alegadamente escrito durante a viagem para o exílio (condenado, no fim do triénio liberal, pela participação no golpe de Riego - 1820), escrevia, findo o sonho liberal: "No es my patria, no... Patria!... No existe / Donde solo hay opresos y opresores / Y quando no tenemos Patria, / Sus hymnos entonar podremos?" (Rivas, 1957: 497).
} 
Por vuestra mano fuerte.

Juradlo, ella os lo manda: ¡Antes la muerte

Que consentir jamás ningún tirano! (Quintana, 1867: 38)

A transubstanciação desta renovada Pátria encontra-se plasmada na Constituição:

Lo que aclara y asegura estos derechos es propriamente la constitución de un estado. No hay, pués, libertad sin constitución. Sin libertad no hay patria. El hombre esclavo jamás puede contar com patria alguna por más que ame aquella en que ha nacido y que para conservarla cumpla todos los deberes que le imponga su razón y aun el capricho del que manda. (Florez Estrada, 1958: 314)

E, por esse motivo, Argüelles, um dos pais da nova Lei Fundamental aprovada em Cádis, exclama, em 1812, empunhando o documento garante da Liberdade: "Españoles! [...] ya tenéis patria, sois ciudadanos" (apud Álvarez Junco, 2003: 133-134). E será este mesmo grito de liberdade, contendo em si todo o programa revolucionário transversal a portugueses e espanhóis, que há-de fazer de Garrett o "Alceu da Revolução de Vinte".

\section{Almeida Garrett: uma estética patriótica ao serviço da Revolução}

Se é comum e comodamente aceite que o processo da Revolução francesa instalou a revolução exemplar, é inegável que, com a sua ascensão a sujeito histórico antropomorfizado e demarcável, a radicalização do novo surja como é: um necessário diálogo com o antigo. Este, no entanto, deve ser entendido numa acepção que terá de ultrapassar a sua habitual identificação com o campo literário, ou, nos melhores casos, estético. Daí que não perceber esse diálogo entre os Antigos e os Modernos faça correr-se o risco de tornar anacrónicas quaisquer perspectivas que não incitem à correlação das diferentes temporalidades que sempre coexistem no mesmo presente histórico. Com efeito, a confluência de experiências revolucionárias estrangeiras, mormente a francesa e a espanhola, convida a que se pense uma certa poética do Liberalismo enquanto diálogo permanente entre a nostalgia da "liberdade dos antigos" e a corporificação da "liberdade dos modernos".

Ora, quer enquanto instrumento de mobilização política, quer enquanto reflexo estético de metamorfoses artísticas, o campo literário acaba por revelar um canto do novo imaginado em suporte antigo - classicista. Parece-nos ser disso modelar o caso do jovem Almeida Garrett que, nos textos do seu ciclo vintista, constrói uma verdadeira estética do patriotismo. Esta, mais do que qualquer outro tema, encerra a aparente ambiguidade: usando uma terminologia dos clássicos (pátria, patriotismo,---- amor da pátria, morrer pela 
pátria, tirania, despotismo, liberdade, lei, etc.), a que amiúde acrescenta a nova semântica de revolução (Koselleck, 2002), não obliterava ser esse também o vocabulário dos modernos, sobretudo quando foram os liberais, tanto em Espanha (Constituição de Cádis, 1812) como em Portugal (1820-22), que sobrepuseram o seu uso àquele que tinha sido feito pelos tradicionalistas anti-napoleónicos. Daí a pertinência da hipótese que nos propomos desenvolver: o liberalismo político não precisou de estar à espera do Romantismo estético para ter voz, tanto no discurso político como no literário.

Com efeito, em Garrett, esta linguagem é produto de uma certa autonomização em face do campo literário. O que se passa é que, tendo como pano de fundo as experi encias históricas já sublinhadas, e fazendo uso de uma dimensão trágico-épica da queda da República Romana e da emergência das primícias do cesarismo, o jovem vate, explorando habilmente a analogia histórica, acabará por, diante de uma intencionalidade política, explorar referencialidades bem conhecidas pelo leitor coevo, cuja formação cultural facilmente o levava a fazer comparações com o seu próprio presente. Com efeito, o arquétipo convocado - para uns, como Garrett, Catão, e, para outros, Brutus - fazia parte do património do humanismo cívico de matriz romana desde os renascentistas italianos e os iluministas (Montesquieu), e impregnara as bandeiras das lutas anti-napoleónicas, fosse em nome da monarquia patriótica anterior ao despotismo absolutista, fosse em consórcio com a renovação do ideal de patria civitatis, feita sob o impacto das teorias do contrato social e da Revolução francesa, particularmente na fase anterior à irrupção do jacobinismo. Trata-se, pois, de perceber o seu posicionamento político diante da herança constitucional dos "antigos" e da inevitável instalação da "liberdade dos modernos", não perdendo de vista qual o modelo estético eleito para esse objectivo.

Ora, esta lógica política, depois dos avanços e recuos do império napoleónico como ressonância da própria ambiguidade do processo revolucionário português -, repercutir-se-á na escolha do temário garrettiano. Não por acaso, antes de 1820, como no decurso do processo revolucionário, coexistirá no jovem Almeida Garrett (estudante ainda em Coimbra e homem já de letras e de espectáculo) o magistério dos clássicos com a lição quer dos revolucionários franceses, quer dos revoltosos anti-napoleónicos que, em Espanha e em Portugal, combateram o despotismo. E os mais avançados de entre estes, vitoriosos, ali, em 1812, logo derrotados em 1814 e, entre nós, em 1817 (gorada a conspiração de Gomes Freire de Andrade), pareciam erguer-se para a batalha definitiva naquele entusiasmante ano de 1820, quando a acção épica de Riego se conjugou com o movimento regenerador português que se iniciou no Porto a 24 de Agosto de 1820.

No entanto, isto ocorreu numa época que se conhecia como é que a Revolução Francesa tinha terminado e, portanto, num tempo em que os revolucionários sabiam que a revolução não devia nem enveredar por métodos radicais, nem pretender apagar as lições 
da história. Daí que, nos países ibéricos, ela tenha sido proclamada como Regeneração e que a afirmação do novo não prescindisse da evocação do antigo, quer clássico, quer nacional.

Garrett, ao datar o ensaio O dia 24 de Agosto do Anno I parece indicar o contrário, pois essa data sugere a adopção da cronologia que foi instaurada pela fase mais radical da Revolução francesa, mesmo que se refira ao início do movimento anti-absolutista do Porto. Porém, não deixa de ser significativo que a obra seja dedicada aos Pais da Pátria, legado romano que, por analogia, foi retomado pelos modernos fautores da constitucionalização da Liberdade.

Os Pais da Pátria são apresentados, pois, como personagens sacralizadas, convertidas em demiurgos da nova pátria cívica, ainda que ancorada na memória do melhor da pátria antiga. "Homens sagrados" de quem estava dependente a Liberdade, a eles coube a modernização da Lei, já que fora da inobservância da fundadora constituição portuguesa (saída das Cortes de Lamego, em 1139) que a tirania se formara. Com esta retórica, comum a Garrett e a outros liberais, insinuava-se que a revolução era uma espécie de integração/superação da "liberdade dos antigos"'.

Assim, a legitimidade do 24 de Agosto assenta na reivindicação do direito de resistência: o despotismo, estando sediado num poder ilegítimo, havia quebrado o velho pactum subjectionis e, portanto, postergado os direitos do povo, agora regenerados e ritualizados a partir da ideia de que cada indivíduo devia ser um cidadão livre (base do conceito de pátria e nação cívicas):

Cumpridas pois pelo povo as condições deste contrato, o rei, que a elas falta, falta à fé, ao juramento, e à santidade dele, e por este ímpio facto desliga os cidadãos da obrigação, em que se tinham constituído. A Nação, pode reclamar os seus direitos e usar de todos os meios - justos - para se manter e restabelecer na posse deles. (Almeida Garrett, 1985: 202)

\footnotetext{
${ }^{9}$ A estética patriótica que temos tentado delinear é devedora, pois, de uma acepção "ética, retórica, laica e civilista" em que "a História cumpria a sua função de celebração de um futuro anterior, ou apenas antevisto, indicando caminhos e preparando o espírito dos leitores para o triunfo esperado" (Araújo, 2009: 256). Com efeito, os caminhos poéticos eleitos pelo autor devem ser lidos à luz da onda estética de cunho patriótico que, síntona com o ocorrido em França e em Espanha, assumia as suas peculiaridades. Entre elas, é sintomática a resistência que o chamado ballet romântico encontrou em Portugal, devido, sobretudo, à persistência das chamadas danças patrióticas, particularmente em voga em França e nos países sob domínio napoleónico, que, em território português encenavam a vitória lusa e as lutas liberais: "Not only were the most epic scenes danced but the participating soldiers, as well as the cavalry and infantry, were also invited to take parti $n$ them (...). Among the most explicit titles we quote: Batalha de Vimeiro (Battle of Vimeiro), Os Patriotas de Aragão ou o Triunfo de Palafox (The patriots of Aragon or Palafox's triumph), O Primeiro Triunfo da Espanha ou o Rendimento de Dupont (Spain's Firts Victory or the surrender of Dupont) (...), Lísia Libertada pelo Herói Lusitano (Lísia freed by the Lusitanian hero), O Déspota Punido ou o Triunfo dos Liberais (The punishment of the Despot or the liberal victory) (...)" (Sasportes, 1990: 36). Também não por acaso, em 1846, Joseph Mazilier, coreógrafo e dançarino francês, cria o célebre ballet, de clara inspiração no cenário ibérico napoleónico, Paquita (o aqui simplesmente sintetizado será oportunamente desenvolvido num outro ensaio em preparação).
} 
No entanto, se o 24 de Agosto tem como motor a existência de uma herança, o seu cerne estava, porém, num direito natural que a celebração de pactos sociais nunca subsumiu: o direito de o povo resistir à tirania e à usurpação, voltando a deter a plenitude da soberania que tinha delegado. Foi em seu nome que se lutou contra Napoleão, como será em seu nome que os revolucionários vintistas, na senda dos seus precursores espanhóis de Cádis, lutarão contra o Absolutismo, e em seu nome se exigia a redefinição do contrato social que existia entre o povo português e a Casa de Bragança, tanto mais da letra e do espírito das boas práticas de relacionamento entre o soberano e os súbditos (não percebo $o$ sentido desta última frase).

O despotismo, ao violentar os direitos naturais do homem e os direitos historicamente adquiridos, surgia para o autor como uma política sem pátria, ou seja, como uma expatriação. Ora, como, segundo a máxima da Enciclopédia, sob o jugo da tirania a pátria não poderia existir, Garrett, não perdendo de vista os excessos de certas interpretações estreitamente republicanas do velho patriotismo cívico, aceitava que a monarquia poderia ser virtuosa e patriótica - desde que enveredasse por e respeitasse a divisão tripartida dos poderes. Nestas condições, a destruição do modo absolutista de objectivação da monarquia seria legítima, mas já não o seria a aniquilação do seu corpo místico, ou daquele que a encarnava, como tinha acontecido em França. E por esse motivo o monarca - mesmo que fisicamente fosse o mesmo indivíduo - teria de passar a ser o primeiro dos cidadãos.

Catão ou a tragédia como encenação estética da virtude cívica

A eleição de uma tragédia para a expressão da exemplaridade da luta contra a tirania e do mito do herói político não é casual, nem uma forma de exercício retórico dos moldes classicistas. A escolha de um herói como Catão, tanto em Garrett como naqueles que o antecederam e dos quais ele se quis demarcar, obedece, pelo menos, a três princípios norteadores conscientemente usados: o ius resistendi, a identificação da liberdade com a pátria, o suicídio:

\section{Catão}

Um Romano, Semprónio, nunca mente.

Décio, não temos nada: débeis, poucos

Moribundos soldados nos defendem,

Frágeis muralhas entre nós e a morte

Intermeiam apenas. Pouco resta

Para a espada de César. Mas não julgues, 
Ainda assim, tão fácil a vitória.

Enquanto a destra segurar um ferro,

Enquanto a voz não fenecer nos lábios,

Enquanto aqui não resfriar de todo

No sangue de Catão, de Roma, o sangue...

- Terra e céus a abandonem! - desvalida

Não ficará de Roma a liberdade. (Almeida Garrett, 1904: 72)

Por esse motivo, o género de herói cívico eleito por Garrett é Catão enquanto modelo de homem de Estado, possuidor de uma sagesse capaz de uma acção pautada pelo conceito respublicano de virtude e, por isso, capaz de ser síntese de uma filosofia moral. Ao contrário de outras versões modernas (como a de Addison), Garrett não acrescenta intrigas amorosas ao principal fio condutor do seu Catão.

Percebe-se, pois o seu motivo é dominantemente ético-político, o que permite pensar que a sua escolha teve pouco que ver com o êxito performativo do seu texto, por um lado, e que estaria certo de que o público dominaria a história em questão, por outro. A radicalização do humanismo cívico do herói, que tem no suicídio a expressão máxima e paradoxal da crença na virtus como possibilidade de mudança face à fortuna e da morte como conhecimento (Nussbaum, 2008), interessou a Garrett, no auge da Revolução Liberal, não como herança árcade, mas como instrumento revolucionário. De facto, em função do posicionamento político do escritor, e da evocação do drama romano da queda da República (modelo de Liberdade porque a predominância da lei e do direito salvaguardava os cidadãos dos arbitrários poderes pessoais), secundarizava-se o seu momento tiranicídico para sinalizar a recusa extrema de se deixar humilhar pela usurpação, simbolizada no novo poder de César $^{10}$. E tenha-se em conta que partimos de uma definição de virtus enquanto capacidade de domar a fortuna, sim, mas sem escamotear que, em Catão, a virtude respublicana mais não é do que a filosofia moral que coloca a acção política sob o imperativo do dever de servir a coisa publica, isto é, o bem comum ${ }^{11}$.

\footnotetext{
${ }^{10}$ A redução da experiência patriótica de Garrett à influência iluminista - ou à presença de Vittorio Alfieri ou Voltaire - de que seria devedor (Monteiro, 2010: 14) deve ser completada, pois os seus conhecimentos sobre esta literatura patriótica eram mais profundos e de remissão para períodos anteriores. E, no plano de influências imediatas, a dádiva dos autores espanhóis já citados, seja do ponto de vista histórico, seja do ponto de vista epistemológico, constitui a chave de compreensão do jovem Garrett. A recepção desse iluminismo por parte de Garrett ganhará se for objecto de uma releitura prevenida contra o equívoco anacrónico que decorre da frequente confusão entre os conceitos de patriotismo com o de nacionalismo, termo que, não obstante ter sido usado pelo abade de Barruel nos finais de Setecentos, só começou a ser popularizado na segunda metade do século XIX. Ora, se o jovem Garrett - aliás, como os seus contemporâneos usou, amiúde o vocábulo "nação", nunca fez dele um "ismo", prova de que nem todo o patriotismo pode ser acriticamente reduzido a um nacionalismo. Em simultâneo, também pensamos que será cientificamente profícuo partir da assunção de que a releitura da herança persiste em função do cenário político europeu - e intercontinental.

${ }^{11}$ Leia-se, no jornal O Patriota, possivelmente pela pena de Garrett: "Ousamos opor Sócrates a Catão: um era mais filósofo e o outro mais Cidadão. Atenas estava já perdida, e Sócrates não tinha mais Pátria que o mundo inteiro: Catão traz sempre a sua no fundo do seu coração; ele não vivia se não para ela, e não podia servi-la" ( $O$ Patriota, 27 de Fevereiro de 1821).
} 
O suicídio heróico surgia, porque apresentado num contexto político revolucionário, como a mais premente das visitas do trágico (Baptista-Pereira, 1990), face ao moderno tempo que o Anno I da Revolução anunciava. Com efeito, com a escolha de Catão, menorizava-se a figura de Brutus (ao contrário de outros dramaturgos anteriores, mas com o mesmo pano de fundo - Shakespeare), e deslocava-se o impulso revolucionário do sacrifício do outro, em ordem a libertar-se a pátria, para o sacrifício do $E u$, não por inoperância, mas sim devido à constatação da corrupção da res publica (Roma), da pátria, e do tempo (sinónimo de que os costumes políticos deviam obedecer à lei e ao direito e não ao interesse individual - usurpação que levaria ao poder pessoal: o cesarismo):

\section{Catão}

[...] Roma, tu dizes,

Não quer a nossa morte. Não, por certo.

Porém, que ideia formas tu da vida?

Vivem acaso em ferro os Romanos?

Não morre o homem quando vive o escravo? (...)

Que cegueira!

Libras sobre a palavra dum tirano

De liberdade esperanças? Tu confias

Tesouros de valor nas mãos do avaro! (...)

Todo o véu da ilusão se rasga em breve;

Cai-Ihe o postiço manto mal seguro,

E em todo o horror da morte se descobre

Da escravidão o lívido esqueleto.

Não, de remédios tais eu não confio;

Ou liberdade, ou morte. Este é o meu voto. (Almeida Garrett, 1904: 62)

O que se pretende vincar neste Catão garrettiano é a aceleração do tempo pessoal por impossibilidade de não ser-se livre, forma essa também de perturbar a fatal roda da fortuna. E se é verdade que, por exemplo, a performance de Caton d'Utique, de La Bruyère, cujas representações imediatamente a seguir ao chamado Terror, em França, têm sido já vistas como a constatação de que após a Revolução chegará sempre a morte e a violência (Monnier, Higonnet, Cobb), no contexto liberal português tratar-se-á precisamente do oposto: para poder evitar-se a treva pós-revolucionária, o suicídio é apresentado como o grande ius resistendi. Talvez melhor: perante a impossibilidade última de não se poder resistir, o suicídio emerge como a prova de que, mesmo aí, o homem é um ser livre, ao preferir a morte à humilhação. Além do mais, a morte individual aparecia como solução 
estóica para a pior das mortes: a da pátria, assassinada às mãos da usurpação e do despotismo.

O patriotismo revolucionário de Almeida Garrett elege, pois, Catão para defender que a aniquilação do Eu só é justa perante a necessidade da afirmação da totalidade cívica. $E$, portanto, a transgressão é identificada com a tirania. É que o gesto de Catão não só visa desencadear efeitos civicamente positivos, como sugere o recalcamento do desfecho tiranicídico do drama romano. A morte sacrificial é aqui rito de regeneração nacional que se quer estender ao rei e à própria instituição monárquica. A suprema forma do direito de resistir concretiza-se, pois, na auto-imolação como canto à Liberdade. O amor pela pátria que Garrett coloca em cena, seguindo os passos de antigos e de modernos, conduz naturalmente aos bons costumes, sendo o mais virtuoso de todos o horaciano Dulce et decorum est pro patria mori, divisa a que as lutas anti-napoleónicas - afinal, um usurpador e um novo César - tinham dado uma nova actualidade.

Ora, Garrett, em cuja lírica coeva a denúncia da tirania e apelo ao cidadão-soldado é evidente, encontrava em Catão o herói ideal para a desculpabilização da Monarquia que, nos escritos liberais, quer poéticos, quer políticos, desresponsabiliza como corpo místico.

Por isso, e tal como a grande maioria dos seus correligionários vintistas, o escritor não incluía o monarca (D. João $\mathrm{VI}$ ) naquilo a que chamava o torpe incenso da venal lisonja os áulicos, culpados pela degeneração da Monarquia em Tirania. A corrupção do regime havia sido causada por um despotismo cortesão que tinha distanciado o monarca dos conselhos da representação nacional e, portanto, da governação de acordo com os costumes. O soberano é, pois, a representação da História, eixo em torno do qual a intriga e os intrigantes se movem (Benjamin, 2003: 65).

A figura do tirano corresponde à corte ministerial que bloqueou o respeito e a renovação do pacto social, fazendo assim perigar a própria radicação do patriotismo. Tal impediu que, sem a revolução, o rei não se tivesse assumido como o primeiro dos cidadãos, logo como um verdadeiro "Pai da Pátria". Esse cognome mereciam-no, antes de todos, os demiurgos da "liberdade dos modernos", construída, porém, não a partir do momento zero da história, mas da reactualização do melhor da herança dos antigos que o Absolutismo tudo tinha feito para ficar esquecida. (volte a recordar-se que foi a esses "Pais da Pátria", e em defesa "da causa dela", que Garrett ofereceu o ensaio O dia vinte e quatro de Agosto do ano $\left.l^{\prime \prime}\right)$.

Secundarizada a questão do tiranicídio, devido, confessa o escritor, à observação dos alheios erros, a radicalização do ius resistendi tem no suicídio quer a superação do trágico (mas não a sua anulação), quer a projecção da crença numa cidade ideal - e, portanto, numa utopia. Catão suicidado (e Garrett esforçou-se por demarcá-lo das demais personagens) corresponde, pois, ao ser histórico, cujo exercício supremo de Liberdade 
permitiria a salvação da História. E, portanto, catarse em nome de valores inegociáveis tanto para a honra cidadã como para purificação da pólis (da res publica), sim, mas também reivindicação da possibilidade emancipatória legada ao homem por uma condição mortal que a herança histórica, enquanto historia magistra vitae, podia integrar e superar. E este também era o horizonte em que se inscrevia a fé regeneradora que animava a ideia moderna de Revolução, ainda que sob a forma secularizada da escatologia cristã:

\section{Catão}

[...] A morte só é termo

Da vida, - da existência não... No íntimo

D'alma pôs Deus o sentimento vivo

Da eternidade. Este viver contínuo

De esperanças, este ansiar pelo futuro,

Este horror da aniquilação, e o vago

Desejo da outra vida mais ditosa,

O que são? - Indistintas, mas seguras

Reminiscências da perdida pátria.

E saudades de voltar a ela. (Levanta-se)

Ver-te-ei, mansão dos justos!... O sepulcro

Não é jazigo é estrada. (Almeida Garrett, 1904: 111)

Por tudo isto, pode dizer-se que, a par do cânone estético da época, foram os problemas nacionais (mas não nacionalistas) que levaram Garrett a ir a Roma, fazer-se Romano e voltar para Portugal, segundo o prefácio da 3a edição do Catão, para apresentar a virtude respublicana antiga a portugueses: "No Catão senti outra coisa, fui a Roma; fui, e fiz-me Romano quanto pude, segundo o ditado manda: mas voltei para Portugal, e pensei de Português para Portugueses" (Almeida Garrett, 1904: 6).

Com isto começou por construir uma estética que antecipa finalidades românticas, sim, vazadas, porém, em temas classicistas; o que convida a não se cair em visões excessivamente evolucionistas e estanques quanto se trata de relacionar o discurso literário com outros e com os quais ele se cruza. Assim, deparamo-nos com um claro aportuguesamento do referente da poética dramatúrgica do jovem, em matriz clássica, porém. Por outro lado, este classicismo não desaguava em puro esteticismo; ele é convocado para ser posto ao serviço de uma função política e social: lutar pelo advento de uma pátria nova, o que, naquele contexto, também significava a regeneração da antiga através da construção de uma nova sociedade.

Portanto, do que se trata quando falamos sobre o Catão de Garrett é, sim, de uma arguta capacidade de reescrever, dialogando, o drama antigo (e, segundo o autor, 
singularmente, quando comparado com Addison) para através dele, articular o antigo com o moderno, sob a égide de um ideal de pátria cívica, fonte afectiva da nova e contratualizada ideia de nação. Basta recordar que o prefácio da primeira edição data de 13 de Março de 1822, que a elaboração da Constituição principia em Janeiro de 1821 e que a sua aprovação só ocorrerá em Setembro de 1822.

O herói, aqui, é o herói cívico, cujo suicídio está longe de ser passional ou melancólico. Em causa está uma autêntica consciência, diria quase militante, da ruína a que o tempo pode levar a sociedade - pelo que à Revolução não foi necessário esperar nem pelo Romantismo (o social, na melhor das hipóteses), nem pelo Realismo/Naturalismo anatómico para sair para a rua. Dir-se-ia mesmo que, com Catão e como Catão, Garrett procurava dar corda à História, sintoma do novíssimo aprendizado da irreversibilidade do futuro enquanto redenção.

\section{Uma porta para o trágico: a emancipação do Outro}

Foi já criteriosamente estudada a influência de Garrett - e o seu interesse - sobre a situação literária e política do Brasil (Ribeiro, 1999; Ribeiro, 2003; Alge, 1980); é necessário, contudo, retomar o lugar que essa reflexão ocupa no âmbito de uma estética que, em permanente tensão entre antigo e moderno, tem na poética do patriotismo o seu pulsar estético. É nessa posição que está, a nosso ver, o poema "O Brasil Liberto", incluso na Lírica de João Mínimo e inicialmente intitulado "A esperada e desejada união de Portugal e Brasil" (Ribeiro, 2003: 360).

Sob a égide ainda do desiderato político de formação - e, em 1820, de constitucionalização - do Reino Unido de Portugal, Brasil e Algarves, "O Brasil Liberto" (Monteiro, 1971: 197) responde ao apelo duplo da harmonização territorial e política sob a forma de império, tanto quanto admite - e encoraja - a independência da colónia. Com efeito, trata-se da defesa, uma vez mais, de ideais arreigadamente clássicos: acima de todos, o patriotismo. Estejamos ou não perante uma crítica ao processo colonial a que o Brasil fora sujeito ${ }^{12}$, o que Garrett acentua, uma vez mais, é a identificação da Liberdade com a Pátria e a transformação de todas as colónias numa pátria constitucional única - ideal a que não pode ser alheio o temor da subalternização da metrópole pela colónia. Sendo evidente que o reconhecimento da colonização enquanto crime e a culpabilização do velho

\footnotetext{
${ }^{12}$ De resto, esta crítica continuará em obras como O roubo das Sabinas e os escritos políticos de Portugal na balança da Europa. Mas também a sua interpretação não pode ficar refém quer de dicotomias estéticas, quer de leituras monolíticas da História - quer ainda de impressionismos biografistas. A presença do Brasil nas inquietações políticas de Garrett deve ser lida, também, à luz de um certo patriotismo imperial que, tendo tido o seu ápice aquando da coroação de D. João como monarca do Reino Unido de Portugal, Brasil e Algarves, em 1818, continuou a fazer-se sentir, muito em virtude da sentida necessidade de constitucionalização do império, por forma a que a metrópole não corresse o risco de se ver substituída pela colónia (Herman, 2007); Jancsó e Pimenta, 2000).
} 
mundo se compaginam com a nova ordem e com o humanismo naturista (Monteiro, 1971: 271), não o é menos - e porque data de 1821 o poema - que havia sido a pátria de Viriato, evitando o exemplo da inexperta Gália, a conseguir a instauração da Liberdade, devendo, então, servir de modelo. E, portanto, tendo como horizonte de esperança uma Liberdade que deve igualar sob a mesma pátria Portugal e Brasil, é que a crítica à colonização exercida como privação da Liberdade natural deve ser ponderada:

Hoje convosco alegres repartimos,

Irmãmente vos damos

Parte igual desse dom que os céus nos deram

Que a tanto custo houvemos.

Lá vai, lá surge em terra, avulta e cresce

A lusa liberdade.

Folgai, folguemos: Portugueses todos,

Em laços igual unidos,

Sobre o seio da pátria reclinados,

Como irmãos viveremos. (Almeida Garrett, 1963: 102)

Fazer de todos os "Portugueses de ambos os hemisférios" cidadãos passaria, inevitavelmente, pelo estabelecimento de um igual pacto social que cimentasse os sentimentos de pertença e assegurasse aquilo a que chama a "feliz concórdia". É este império constitucionalizado que corporiza uma acção emancipatória assente na união de dois reinos que deve ser paradigmática diante de uma encanecida Europa - e assim salvaguardar a territorialidade e autonomia do império português. Depois da colonização tirana, a colónia seria, pois, a destinatária do contra-exemplo salvador.

O que significa, em primeira instância, que à universalidade dos desígnios de emancipação, o Reino Unido - e Portugal, por ter derrotado o jugo do despotismo - surgia como resposta modelar e porta-voz de uma libertação crescente. Versos como "Lá surge,I nesse mesmo terreno/ Quem vingará a opressa natureza,/ E a mão the dá que se erga" trazem inscritos em si a progressiva revolução que fará do mundo o reino total da liberdade, tornando todos os horizontes, à distância adivinhados, possibilidades regeneradoras. No mundo que se erguia após o estrépito da antiga e opressora ordem das coisas, a dilatação do Novo Mundo estava, finalmente, vocacionada para si mesmo, como se os territórios colonizados conhecessem uma fertilidade revolucionária (a que o autor atribui os rostos de Franklin, Washington e Penn) que só um tempo irreversível e uma revolução permanente haviam podido mostrar.

O apelo que Garrett faz à independência do Brasil ganha em ser lido segundo estes pressupostos. A independência que deveria ser exigida em caso do trágico retorno do 
despotismo à metrópole assenta, sobretudo, na quebra da crença na autoridade (BaptistaPereira, 1990: 96) como garante falso de pertença:

\section{$[\ldots]$}

Mas, se em má hora um dia

(Longe vá negro agoiro!) dessa escura

Caverna onde o prendemos,

Ressurgir férreo o despotismo ao trono,

Então hasteai ousados

Os pendões da sincera independência.

Sim, da paterna casa

Salvai vós as relíquias, os tesouros,

Antes que os roube o monstro. (Almeida Garrett, 1963: 102-103)

O Brasil é apresentado, pois, como prova da possibilidade de uma emancipação universal (Koselleck, 2002) e, por esse motivo, projecção de uma utopia reveladora da revolução acontecida mas (hipoteticamente) malograda. Enquanto referente, a colónia era configurada como uma espécie de cidadão colectivo, para quem a cidadania, sendo o seu sujeito o homo emancipator, continha as premissas da independência. O que surpreende nas palavras do jovem Garrett é a assunção da responsabilidade, escapando, pois, a uma visão apologética do passado. Consequentemente, o novíssimo escritor faz o seu horizonte de Progresso dialogar com a servidão pretérita. Nesse sentido, o poder emancipatório que confere ao Brasil, suportado pelo reconhecimento da responsabilidade histórica, acaba por desenhar um percurso da redenção que, sem os requintes ideológicos de uma teologia política da redenção, resgata a sua própria poética de um criticismo datado para dela fazer voz da dolorosa privação da Liberdade do Outro.

Em "O Brasil Liberto" insinua-se, pois, a consciência sobre o eterno retorno da corrupção do poder, em plena acção revolucionária - condição generosamente inglória para que o trágico se cumpra (Jaspers, 1991). Neste momento de indecidibilidade se joga de novo a tirania que se abaterá sobre a Pátria. Recorde-se que o monarca, no Rio, ainda só havia jurado as Bases da Constituição, e, no entanto, a pluralidade dos monstros apontados por Garrett circunscreve ainda mais as máscaras daqueles que haverão de formar essa larga personagem que é a intriga (Benjamin, 2003: 156). Ao monarca caberá, sempre e unicamente, o papel de herói e de mártir, e nunca o de tirano. Pelo contrário. É a sempre materialização de um poder adulterado que o escritor constrói em torno da figura, mais tarde dita paternal, de D. João. Pelo que a sugestão de que a Liberdade podia ser efémera reflectindo-se, assim, enquanto face magoada da transitoriedade das coisas - lega ao Outro, que fora a colónia, um conceito de emancipação que the permite uma espécie de 
permanência política e racional (Koselleck, 2002). Nesse movimento perpétuo, a emancipação iterativa do Outro redimia a possível tragédia silenciosa da metrópole, funcionando, assim, como máscara messiânica da sua própria libertação.

Inequívoca crença no Progresso e certeza inabalável de que a menoridade havia apenas sido um estádio, parece, pois, que a presença do Brasil - e tendo em conta, por ora, apenas o texto eleito - imprime à poética revolucionária de Almeida Garrett bem mais do que a crítica ao processo colonizador empreendido por Portugal. Do que se trata é de esteticamente explicitar "une longue progression d'un état initial vers un état final, dont le temps historique serait le vecteur" (Moses, 1992: 75-76) e, por isso mesmo, um ensaio de utopia. E, talvez de entre todas as composições de temática revolucionária, o texto em causa seja o que mais grita por uma alternativa utópica, ao localizar fora da pátria mas fruto dela o lugar da feliz concórdia. De certa forma, a Pátria ficaria à espera da Redenção através da metamorfose da colónia em utopia eleita - forma de se recusar o fim da História e de definir a espera do futuro. O escritor oferece, pois, aos seus companheiros brasileiros uma hipótese de aceleração da História, o que instala, no desejado quadro de paz, a sublime constatação das dessincronias das experiências históricas. O presente em que Garrett escreve é, conscientemente, o presente-trampolim (Moses, 1992: 90): aquele em que são confessadas diferentes historicidades, sendo essa sentida ruptura que matiza de contornos trágicos a tensão - e não apenas defesa - em face do outro mundo, também ele português.

E, por isso, a consciência do trágico que podemos ler em Garrett não produz a aclamada e fácil crítica à ambição da metrópole; esta, a existir, será apenas parte de uma consciência histórica que, por isso mesmo, se não desloca para fora do seu mundo, do seu con-texto. E é em virtude desta historicidade que remata "O Brasil liberto" com um magnífico instante de "humilitas" (Baptista-Pereira, 1990: 155), pondo nas mãos do Outro a catarse da iminência do seu próprio fim. Em última análise, a destruição do seu presente libertador mais contribui para a encenação do trágico e para que somente Catão tivesse feito sentido na escrita patriótica de Garrett. Sendo sujeito mediador (Catroga, 2009: 188-189), a metrópole-pátria, de que o herói romano será metáfora, assume-se como actor na construção da consciência e da vontade do Outro, auto-mutilando-se a si e dessa forma garantindo, mais do que a exemplaridade, uma etapa mais eliminada e, consequentemente, uma História mais célere. Nesse gesto fica gravada, pois, a moderna sensibilidade política, tal como a Península Ibérica a desenhou nas suas brancas noites liberais. Noites brancas para que a Revelação não parasse. 


\section{Bibliografia}

ALGE, Carlos d' (1980). As relações brasileiras de Almeida Garrett. Rio de Janeiro: Edições Tempo Brasileiro, Brasília, Instituto Nacional do Livro.

AlvareZ Junco, José (2003). Mater Dolorosa. La idea de España en el siglo XIX. Madrid: Taurus.

AraúJo, Ana Cristina (2009). "Memória e mitos da Guerra Pensinsular em Portugal. A História Geral da Invasão dos Franceses de José Acúrsio das Neves". In: Revista de História das Ideias, vol. 29, 2009, pp. 241-274.

BAPtISTA-Pereira, Miguel (1990). Modernidade e Tempo. Para uma leitura do discurso moderno. Coimbra: Minerva.

BACZKO, Bronislaw (2001). Lumières de l'Utopie. Paris: Payot.

BENJAMIN, Walter (2003). The origin of German tragic drama. London: Verso.

CATROGA, Fernando (2008). "Pátria, Nação, Nacionalismo”. In: Luís Reis Torgal, Fernando Tavares Pimenta, Julião Soares Sousa. Comunidades Imaginadas. Nação e Nacionalismos em África. Coimbra: Imprensa da Universidade, pp. 9-39.

Catroga, Fernando (2008ª). "Os Pais da Pátria Liberal”. In: Revista de História da Sociedade e da Cultura, no 8, pp. 235-280.

CAtroga, Fernando (2009). "Em nome de... A heroicização do tiranicídio", In: Fernando Augusto Machado et al., Caminhos de cultura em Portugal. Homenagem ao Prof. Doutor Norberto Cunha, Vila Nova de Famalicão, Húmus, pp. 125-160.

CATROGA, Fernando (2009a). "A Constitucionalização da Virtude Cívica (os seus ecos nas Cortes vintistas)". In: Revista de História das Ideias, no 29, pp. 275-345.

Catroga, Fernando $\left(2009^{b}\right)$. Os Passos do Homem como Restolho do Tempo. Coimbra: Almedina.

Catroga, Fernando (2011). Ensaio Respublicano. Lisboa : Fundação Francisco Manuel dos Santos.

DESMONS, Eric (2001). Mourir pour la Patrie? Paris: PUF. FERnÁNDEZ SEBASTIÁN, Javier (2005). “Estado, Nación y Patria en el lenguaje político español. Datos lexicométricos y notas para una historia conceptual”. In: Patria, Nación, Estado, núm. extraordinario de la Revista de Historia Militar, XLIX, pp. 159-219. Florez Estrada, Álvaro (1958). Obras, II, tomo CXIII. Madrid: Atlas.

GARCíA CÁRCEL, Ricardo (2007). El sueño de la nación indomable. Los mitos de la guerra de la independencia, Madrid, Temas de Hoy, 2007.

GARCIA GodoY, Maria Teresa (1998). Las Cortes de Cádiz y America. El primer vocabulario liberal español y mejicano (1810-1814). Sevilha: Diputación de Sevilla.

GARRETT, Almeida (1904). Catão, Lisboa, Livraria Pacheco. 
GarRetT, Almeida (1963). Lírica Completa. Lisboa: Arcádia.

GarRetT, Almeida (1985). Obra Política. Escritos do Vintismo (1820-23). Lisboa: Editorial Estampa.

GODECHOT, Jacques (1971). "Nation, patrie, nationalisme et patriotisme en France au XVIII" siècle". In: Actes du Colloque Patriotisme et Nationalisme en Europe à l'époque de la Révolution française et de Napoléon, III Congrès International des Sciences historiques (Moscou, 19 août 1970). Paris : Société des Études Robespierristes, pp.7-27. Godoy, María Teresa (1998). Las Cortes de Cádiz y América. El primer vocabulário liberal español y mejicano (1810-1814). Sevilla : Deputation de Sevilla.

GUERRA, François-Xavier (2009). Modernidad e Independencias. Ensayos sobre las Revoluciones Hispánicas. Madrid: Encuentro.

HERMAN, Jacqueline (2007). "O Rei da América: notas sobre a aclamação tardia de D. João VI no Brasil”. In: Topoi, v. 8, no 15, pp. 124-158.

JANCSÓ, István e PIMENTA, João Paulo, (2000). "Peças de um mosaico, ou apontamentos para o estudo da emergência da identidade nacional brasileira". In: Revista de História das Ideias, no 21, pp. 389-440.

JASPERS, Karl (1991). "Basic characteristics of the tragic". In: Arthur Coffin, The Questions of Tragedy. Edwin Mellen Press.

Jovellanos, Gaspar (1962). Obras Sociales y Políticas. Madrid: Publicaciones Españolas. Koselleck, Reinhart (2002). The Practice of conceptual History. Timing History, spacing concepts. California: Stanford University Press.

LOCKE, John (1824). Two Treatises on Government. Harvard College Library. MARTíNEZ DE LA ROSA (1837). Obras Literarias. Paris: Julio Didot. MONNIER, Raymonde (2006). "Patrie, Patriotisme des Lumières à la Révolution. Sentiment de la Patrie et culte des héros". In: Dictionnaire des usages socio-politiques (1770-1815), Fascicule 8, Paris: Honoré Champion.

MONTEIRO, Ofélia Paiva (1971). A formação de Almeida Garrett: experiência e criação.

Coimbra: Centro de Estudos Românicos.

MONTEIRO, Ofélia Paiva (2010). Estudos Garrettianos. Rio de Janeiro : EDUERJ.

MONTESQUIEU (1854). CEuvres Complètes. Paris : Didot Frères.

Moses, Stéphane (1992). L'Ange de l'Histoire. Rosenzweig, Benjamin, Scholem. Paris: Seuil.

Nussbaum, Martha (2008). "The morality of pity". In: Rita Felski, Rethinking Tragedy. The John Hopkins University Press.

O Patriota, ํㅡ 23, 27 de Fevereiro de 1821.

ORTEGA y GASSET (2007). Notas de andar e ver. Viagens, gentes e países. Lisboa: Fim de Século. 
QUINTANA, José Manuel (1867). Obras Completas. Madrid: M. Rivadeneyra.

Renan, Ernst (1887). Discours et Conférences. Paris: Calmann-Lévy.

RIBEIRO, Maria Aparecida (2003). "De Mestre a parceiro: Garrett e os românticos do Brasil". In: Maria Ofélia Paiva Monteiro e Maria Helena Santana, Garrett: um romântico, um moderno, 2 vol. Lisboa: Imprensa Nacional - Casa da Moeda, pp. 359-371.

RIBEIRO, Maria Aparecida (1999). "Imagens do Brasil na obra de Garrett. Invocações e exorcismos". In Camões. Revista de Letras e Culturas Lusófonas, ํㅡ 4, pp. 115-127. RiEGo, Rafael de (1976). La Revolución de 1820, dia a dia. Cartas, escritos e discursos. Madrid: Editorial Tecnos.

RIVAS, Duque de (1957). Obras Completas. Madrid: Atlas.

ROBESPIERRE (1965). Discours et Rapports à la Convention, "Sur les principes de morale politique qui doivent guider la Convention nationale dans l'administration intérieure de la République Prononcé à la Convention le 5 février 1794". Paris: Union Générale d'Editions. RosanVALLON, Pierre (2004). Le modèle politique français. La société civile contre le jacobinisme de 1789 à nos jours. Paris: Seuil.

SAINT-JUST (2004). CEuvres Complètes. Paris: Gallimard.

SASPORTES, José e RiBeiRo, António Pinto (1990). History of Dance, Lisboa, Imprensa Nacional - Casa da Moeda.

SAUER, Elizabeth e WRIGHT, Julia (2010). Reading the nation in English Literature. London \& New York: Routledge.

STEUCKARDT, Agnès (2006). "Patrie, de la philosophie politique à la rhétorique révolutionnaire : le parcours de Marat”. In: Dictionnaire des usages socio-politiques (17701815), Fascicule 8. Paris: Honoré Champion, pp. 135-158.

UGARTEMENDIA ECEIZABARRENA, Juan Ignacio (1999). "El derecho de resistencia y su «Constitucionalización». In: Revista de Estudios Políticos (Nueva Época), num. 103, pp. 213245.

VeRDELHo, Paulo (1981). As Palavras e as ideias na Revolução Liberal de 1820. Coimbra: INIC.

VILAR, Pierre (1971). "Patrie et nation dans le vocabulaire de la guerre de l'indépendance espagnole". In: Actes du Colloque Patriotisme et Nationalisme en Europe à l'époque de la Révolution française et de Napoléon, III Congrès International des Sciences historiques (Moscou, 19 août 1970). Paris: Société des Études Robespierristes, pp. 167-201. VIROLI, Maurizio (2001). Per Amore della patria. Patriottismo e nazionalismo nella storia. Roma-Bari: Laterza. 


\section{Fontes digitais}

http://www.conseil-constitutionnel.fr/conseil-constitutionnel/francais/la-constitution/lesconstitutions-de-la-france/constitution-de-1791.5082.html (23-04-2011).

http://debates.parlamento.pt/?pid=mc (23-04-2011) 